
notherapy, we noticed in all cases a subjective and objective amelioration of health condition as well as an inhibition of the proliferation of tumor growth over periods of time which varied individually. One patient with a papillary cystadenocarcinoma $\left(T_{4} N_{x} M_{1 c}\right)$ was even pretreated with the ultrafiltrate of cultured ovarian carcinoma cells of a different patient, since the extraction of her own carcinoma cells was impossible because of a peritonitis. The moribund woman has completely recovered after 4 months. She is still given a triple-drug therapy. The former ascites has disappeared. The remission of the tumor is still continuing.

In the 16 patients treated in the manner described above, no side effects were detected after adjuvant immunotherapy, which could have led to a therapeutic interruption. So far 11 patients survived $4-10$ ple described above. After adjuvant immu-

months after the beginning of the therapy. Tumor remission continued in 8 of them. Four patients died between 3 and 10 months. Another patient died after one month because of intestinal obstruction (ileus). A detailed report about further results of treatment will follow after the enlargement of patient material, observation time, as well as an additional improvement of the adjuvant immunotherapy.

Received April 26, 1978

1. DBP-Anmeldung $P \quad$ 28-02-277.7 vom
19.1.1978

2. Limburg, H., Krahe, M.: Dtsch. Med. Wochenschr. 89, 1938 (1964)

3. Mittermayer, Ch., Sandritter, W.: Histochemie 12, 67 (1968); Riede, U.N., Kaden, P., Mittermayer, Ch.: Med. Welt 26, 122 (1973); Sandritter, W.: Verh. Anat, Ges. 71, $59(1977)$

\section{The Roe Deer Intermediate Host of Different Coccidia}

R. Entzeroth and E. Scholtyseck

Abteilung für Protozoologie, Zoologisches Institut der Universität, D-5300 Bonn

E. Greuel

Institut für Anatomie, Physiologie und Hygiene der Haustiere

(Forschungsstation für Geflügelkrankheiten) der Universität, D-5300 Bonn

In 1843 the German zoologist F. Miescher described tubelike cysts (Mieschersche Schläuche) in the muscles of a mouse caused by a protozoan parasite. Recent research has demonstrated a high infection rate of this parasite in domestic and game animals [2]. In 1972 Rommel and Heydorn discovered the life cycle of sarcosporids of cattle and sheep. They fed meat from these herbivores to cats and dogs and received typical sporulated oocysts of the Isospora type [6].

Oesophagus, diaphragm, and peritoneal muscles of roe deer (Capreolus capreolus) in which sarcocysts had been histologically demonstrated were fed to coccidian-free carnivores: a fox, a dog, and a cat. After a prepatency of 8 days the fox shed sporulated sporocysts (Fig. 1e) that measured $8.5 \times 14.5 \mu \mathrm{m}$, and after 11 days unsporulated oocysts (Fig. 1 a) of $13.1 \times 11.6 \mu \mathrm{m}$. The latter resembled the small form of $I s o$ - spora bigemina (Hammondia) described by Heydorn [5] and Rommel [7]. The dog fed with roe-deer meat shed sporulated sporocysts $(15.6 \times 10.0 \mu \mathrm{m})$ of the Sarcocystis type after a prepatency of 10-14 days. The sporocysts were collected for 51 days. The young cat also fed with roe-deer muscle shed unsporulated oocysts $(12.2 \times 10.9 \mu \mathrm{m})$ 8 days p.i. (Fig. 1 c).

To identify the smaller Isospora type of the fox and that of the cat (Fig. $1 \mathrm{~b}, \mathrm{~d}$ ), sporulated oocysts were inoculated into mice. We found typical Toxoplasma cysts (Fig. 1f) in the brain of the mice and cysts typical of Hammondia hammondi in the muscles of the mice. The oocysts of the fox did not cause any visible infection in mice. Electron-microscope studies of natural infected roe-deer muscle showed, besides two known types of sarcosporidian cysts $[1,8]$, a third type of cyst with threadlike protrusions of 5-6 $\mu \mathrm{m}$. The application of

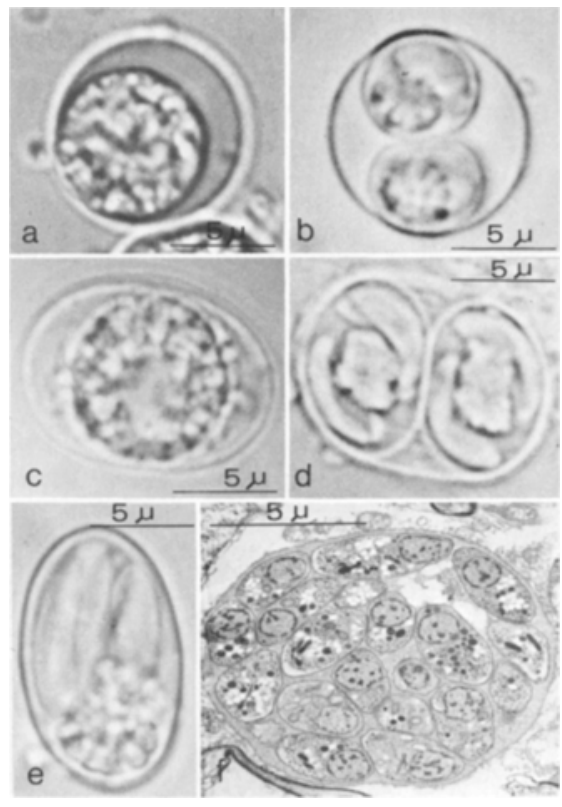

Fig. 1. Coccidian oocysts and a sporocyst after feeding roe-deer meat to a fox, a cat, and a dog. (a) Hammondia hammondi; unsporulated oocyst from the fox. (b) H. hammondi; sporulated oocysts after 3 days. (c) Toxoplasma gondii; unsporulated oocyst from the cat. (d) T. gondii; sporulated oocyst after 3 days. (e) Sarcocystis sp. from the fox and the dog. (f) $T$. gondii; electron micrograph of a cyst in the brain of a mouse

different techniques led to the conclusion that, besides three ultramorphologically different sarcosporidian cysts, the roe-deer muscles contain coccidia of the genera Toxoplasma and Hammondia.

Received April 6, 1978

1. Bergmann, V., Kinder, E.: Mh. Vet. Med. 31, 785 (1976)

2. Drost, S., Graumann, H.-D.: ibid. 29, 620 (1974)

3. Erber, M., Boch, J.: Berl. Münch. Tierärztl. Wschr. 89, 449 (1976)

4. Frenkel, J.K.: J. Parasitol. 63, 611 (1977)

5. Heydorn, A.O.: Berl. Münch. Tierärztl. Wschr. 86, 323 (1973)

6. Rommel, M., Heydorn, A.O., Gruber, F.: ibid. 85, 101 (1972)

7. Rommel, M., Seyerl, F.v.: ibid. 89,398 (1976)

8. Schramlová, J., Blazek, K.: Z. Parasitenkd. 55,43 (1978) 